\title{
Research \\ Social-Ecological Scale Mismatches and the Collapse of the Sea Urchin Fishery in Maine, USA
}

$\underline{\text { Teresa R. Johnson }}^{1}, \underline{\text { James A. Wilson }}^{1}{ }^{1} \underline{\text { Caitlin Cleaver }}^{1}{ }^{\text {, and Robert L. Vadas }}{ }^{1,2}$

\begin{abstract}
Scale mismatches result in incomplete or ambiguous feedback that impairs the ability to learn and adapt and, ultimately, to sustain natural resources. Our aim is to examine the sea urchin fishery in Maine, USA to better understand the multiscale, social, and biophysical conditions that are important for the design of institutions that might be able to sustain the resource. During the late 1980s and 1990s, the Maine sea urchin fishery was a classic gold rush fishery. In the beginning, the fishery was characterized by an abundant resource with little to no harvesting activity, followed by a period of rapid increase in landings and effort that led to a subsequent and persistent decline in the sea urchin population and a significant reduction in effort. We conducted semistructured interviews with scientists and experienced fishermen to understand the multiscale, social, and biophysical conditions that influence fishermen's harvesting strategies, and the implications of this for the design of institutions for successful resource management. The current co-management system includes an advisory body made up of industry members and scientists it also includes limited entry, and additional input control mechanisms. Many of these measures are implemented at a very broad scale; however, we find that the ecological conditions relevant to the sustainable processes occur at the scale of individual fishing sites or ledges, which is a much finer scale than current management. Therefore, the comanagement system maintains an open access system and leaves few incentives for the development of sustainable harvesting strategies among fishermen. The clear suggestion is that the appropriate management system would be one that directly addresses the fine scale ecological and social dynamics within this fishery and gives fishermen property rights over individual ledges (for example, leases). After having briefly reviewed experiences in Canada and Chile, we found that knowledge of the coupled natural and human system at the fine scale is necessary if we are to assess the feasibility of area management in this fishery, because what works in one fishery does not necessarily work in another.
\end{abstract}

Key Words: collective action; co-management; fisheries management; kelp; Maine, USA; ocean fisheries; scale mismatches; sea urchin fishery

\section{INTRODUCTION}

Ocean fisheries are notorious examples of the failure to govern human activity in ways that sustain major natural resources (Pauly et al. 2002, Myers and Worm 2003, Hutchings and Reynolds 2004, Worm et al. 2006). Although a large number of preconditions consistent with the sustainable use of common-pool resources have been identified (Ostrom 1990, Agrawal 2003), the dynamics that generate those preconditions continue to be a significant area of research and debate. For example, well-designed property rights systems, such as co-management regimes, are generally expected to counter the tragedy of the commons (Feeny et al. 1990), but in some cases they can result in fishing behavior that erodes the underlying population structure and the system itself (Wilson 2006). In other words, what works well in one fishery may fail completely in another; there are no panaceas (Ostrom 2007). Our aim here is to examine the sea urchin fishery in Maine, USA to better understand the multiscale, social, and biophysical conditions that are important for the design of institutions which might be able to sustain the resource.

For reasons we detail below, we focused our attention on issues of scale. Many scholars attribute resource management and sustainability problems in coupled human and natural systems (Liu et al. 2007) to scale mismatches between the social (institutional) and ecological components (Berkes and Folke 1998, Young 2002, Borgström et al. 2006, Cash et al. 2006, Crowder et al. 2006, Cumming et al. 2006, Folke et al. 2007). Spatial scale mismatches in the ocean can be a result of jurisdictional boundaries that are too large or too small, or they may occur when administrative boundaries cross significant ecological boundaries (Crowder et al. 2006). Most critically, when the scale of management institutions is not congruent with the scale of the ecological system, the result is incomplete or ambiguous feedback that impairs the ability to learn and adapt. This, ultimately, hinders efforts to sustain the resource (Ostrom, 1990; Berkes et al. 2006; Wilson 2006).

The competitive and cooperative relationships that emerge from fishermen's search and learning processes are key elements of self-governance or community management (Wilson et al. 2007). We, therefore, also focus our analysis on how the fishery's fine-scale dynamics influence the scale of knowledge that fishermen have of the resource and of the circumstances under which they cooperate. In short, the scale of management directly influences the scale of fishermen's 
harvesting operations, their ability to learn and adapt, and hence the circumstances under which they are likely to cooperate for collective action.

Among the world's fisheries there are interesting examples of successful governance (McCay and Acheson 1987, Wilson et al. 2003, Hilborn 2007) where management institutions adequately restrain fishermen's harvesting behavior at appropriate scales (e.g., Dyer and McGoodwin 1994, Acheson 2003, Basurto 2005). The Maine lobster fishery, for example, is a widely cited example of successful self-governance, where informal and formal management institutions are matched to the ecological conditions of the resource in ways that enable sustainable harvesting practices (Acheson 2003). Basurto (2008) illustrated how the biological and ecological factors of a resource can influence fishing practices in ways that promote sustainable self-governance in small-scale fishing in the Gulf of California, Mexico. In this successful case of selfgovernance (Basurto 2005), the resource is sedentary and fishing practices appear well matched to the resource (Basurto 2008). Here we similarly explore how the particular social, ecological, and governance conditions of the Maine urchin fishery influence fishermen's harvesting strategies and, subsequently, the overall sustainability of the system.

As detailed below, the State of Maine created a comanagement system in 1996. An advisory council of industry members and independent scientists was charged with providing management advice to State managers, and two management zones were created with the understanding that local conditions called for more locally specified rules. Although co-management is generally expected to better align individual and social interests and, consequently, to be more likely to prevent the tragedy of the commons (Feeny et al. 1990), this clearly did not happen in the urchin fishery; the system has been unable to halt the rapid and continued depletion of the resource, much less manage a rebuilding of the stock. Statewide landings show a typical boom and bust fishery with landings peaking in 1993 and subsequently declining (Maine DMR landings; Fig. 1) with the depletion of the stock biomass (Chen and Hunter 2003).

Maine is not the only place to attempt co-management of sea urchins (Andrew et al. 2002), nor is it the only site where such co-management attempts have failed to achieve sustainable resource use. Area-based (or leasehold) management of sea urchins was attempted in Nova Scotia, Canada but this system failed to achieve success apparently because the scale of management areas did not match the ability of fishermen to properly manage the full extent of their leaseholds (Miller and Nolan 2008). Other efforts at community-based or comanagement of sea urchins have occurred in Japan and Mexico (Andrew et al. 2002), with similar outcomes (Berkes et al. 2006, Andrew et al. 2002). In Chile, where territorial user rights (TURFs) manage multiple benthic species, efforts to sustain the sea urchin fishery appear to have had more success (Moreno et al. 2007). A comprehensive assessment of these other sea urchin co-management systems is beyond the scope of this paper, but their relatively uniform results underscore the global challenge of managing fisheries for sea urchin and other sedentary species.

Fig. 1. Sea urchin landings in Maine, and value by Zone, from 1987 to 2009. Source: Maine Department of Marine Resources.

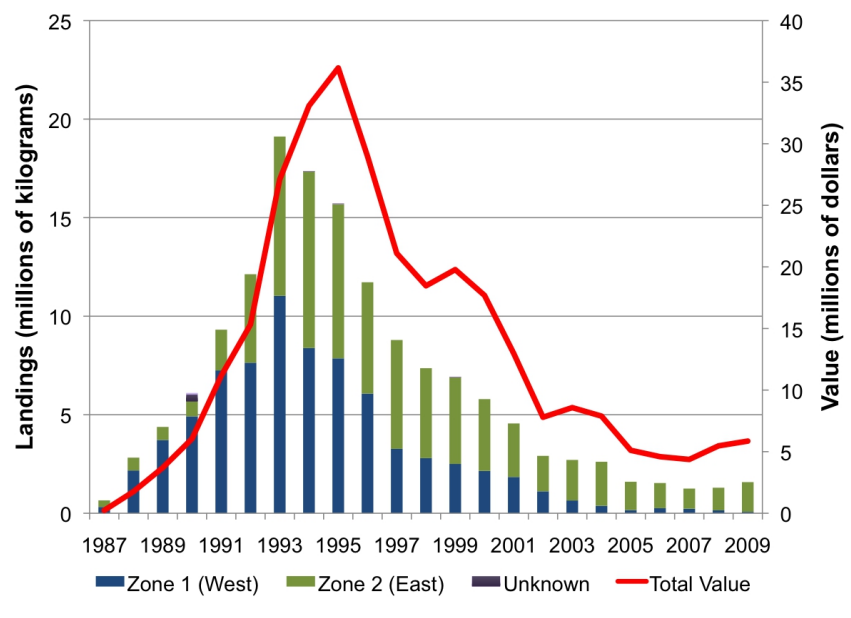

Our examination of the Maine fishery is focused on its finescale dynamics. Overharvesting has been characterized by the transition of very local places (referred to here as "ledges") from urchin-dominated to kelp-dominated alternative stable states. In the urchin-dominated state, kelp and other seaweeds are virtually absent except in areas of high turbulence, e.g., the shallow zone of exposed shorelines. The kelp-dominated state occurs when urchins are removed by harvesting. This allows kelp to grow. Urchin predators colonize the kelp and extirpate the local population of urchins, leading to a new stable state for the local system (McNaught 1999, Steneck et al. 2002). When these fine-scale mechanisms are taken into account, the decline in total state landings (Fig. 1) is seen as the sequential overharvesting of individual ledges, i.e., the result is that the local system "flips", rather than a uniform reduction in the density of urchins along the entire coast (Fig. 2). This has important implications for the biological scale at which feedback about the mechanisms of human impacts can be found.

We begin with some necessary background information, present the results of our analysis, and briefly examine sea urchin management institutions in Atlantic Canada and Chile. We conclude with some implications for the design of management institutions that might help sustain the Maine fishery. 
Fig. 2. In the traditional broad-scale view, state-wide landings occurred at a faster rate than that of the population, leading to declines in population and landings (dashed lines). Slowing the broad-scale rate of harvest is the implied policy. In an alternative view, emphasizing finer scale ecology, the mechanism leading to a decline in the population and harvests was the serial extirpation (flip) of numerous ledges (solid line), i.e., small local "systems". The implied policy would be one that addresses the system state on each ledge.

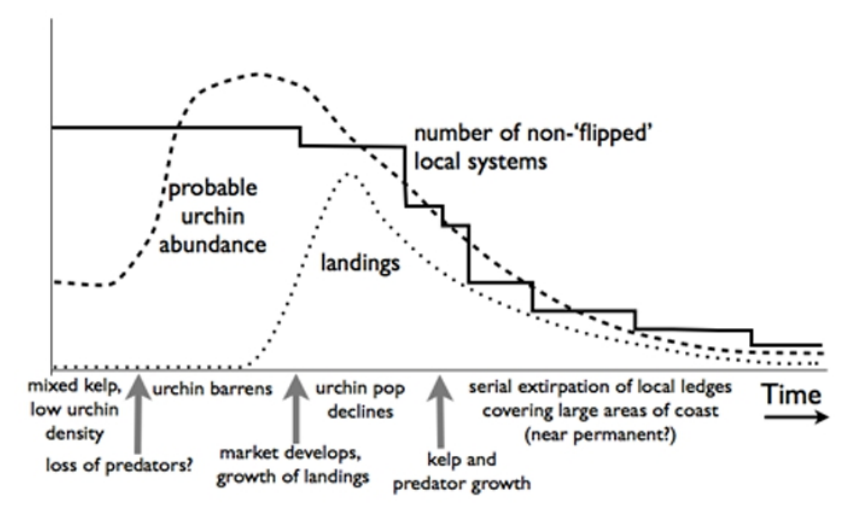

\section{BACKGROUND}

In this section, we briefly describe aspects of the history, management, and biology of the sea urchin, Strongylocentrotus droebachiensis, that are most relevant to understanding fishermen's harvesting strategies. These factors strongly influence the nature of the feedback fishermen receive from their interaction with the resource and other fishermen. It is this feedback that drives fishermen's harvesting strategies and the conditions under which they are likely to cooperate or otherwise engage in practices necessary for the sustainability of the resource.

\section{History and management of the sea urchin fishery in Maine}

The birth and near death of the sea urchin fishery in Maine was part of the worldwide sequential depletion of this resource (Botsford et al. 2004, Berkes et al. 2006). There was a small fishery from the 1950s to the 1980s in Maine. In the mid 1980s, with the loss of domestic supplies, imports to the Japanese market began to arrive from increasingly distant locations (Berkes et al. 2006). In 1987 the market reached Maine and instigated an explosive boom. Urchins covered extensive areas of shallow, and near-shore ocean bottom was characterized as urchin barrens. This incredible abundance made harvesting very easy and, even with relatively low prices, generated large incomes leading to very rapid growth in the fishery. Initial harvests concentrated in the southwestern region of the state, near the location of the first buyers and processing plants, but rapidly spread eastward (Fig. 1). Previously formed business relationships led to rapid distribution of knowledge about the market opportunity and required little or no new local infrastructure (Laur 2001, 2005).

In 1987, $635,040 \mathrm{~kg}$ were landed with a total value of US\$236,391 (Fig. 1). Total landings peaked in 1993 at around $19,051,200 \mathrm{~kg}$, while revenues peaked in 1995 at US\$35.5 million. By 1994, nearly 3000 licensed divers (using SCUBA) and draggers (using light bottom trawl gear) harvested the resource (Fig. 3). Divers currently account for about $60 \%$ of the catch, down from about $80 \%$; dragging is more common in eastern Maine (Zone 2) where the fishery persists and where depth, and strong tidal currents and resulting turbulence, make it more difficult to dive (Fig. 3).

Fig. 3. Numbers and types of sea urchin harvesters in Maine, from 1992 to 2009. Source: Maine Department of Marine Resources.

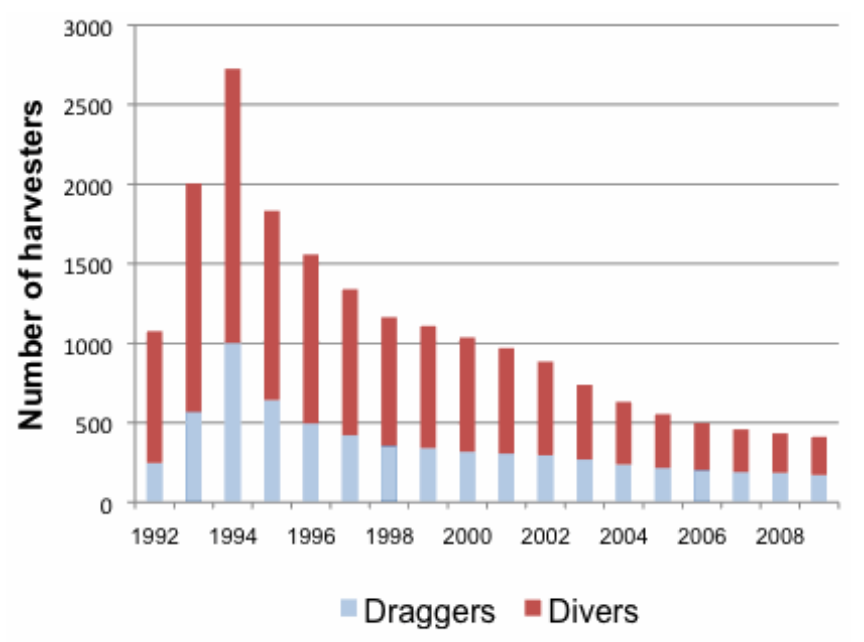

In the early 1990s, the Maine Department of Marine Resources (Maine DMR), the agency responsible for managing the State's fisheries, created an informal, advisory committee that included scientists and members of the industry. Starting in1992 the Maine DMR required fishermen to have a special license to harvest urchins. The following year more rules came into effect, including a $5.1-\mathrm{cm}$ minimum size, a diver and tender license requirement, a closed season during the summer, and a limit on the size of bottom trawls. In 1994, the State implemented a moratorium on licenses and created two fishing zones with seasons (Fig. 4). The rationale for the two management zones was the timing of spawning, which starts in the southwest and takes about 4 weeks to spread along the coast (Seward 2002). 
Fig. 4. Map of the sea urchin co-management zones in Maine.

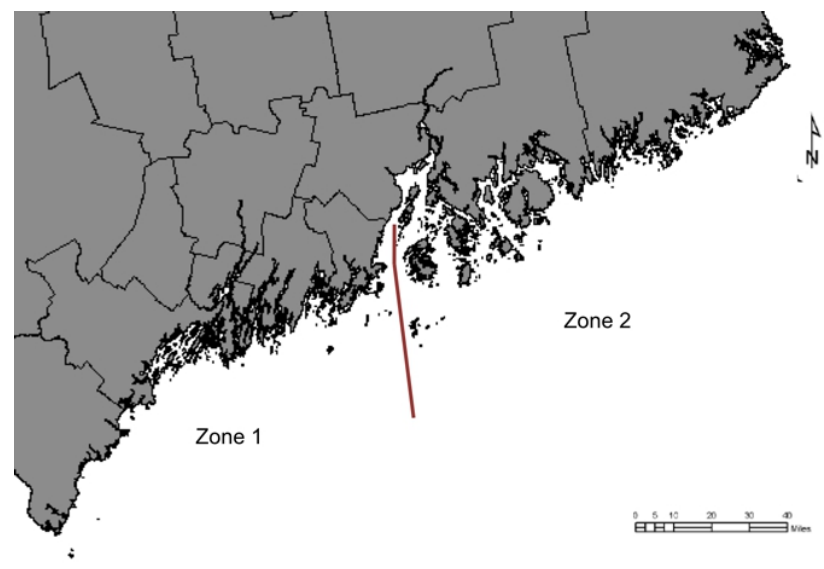

In 1996, a formal co-management system was established with the creation of the Sea Urchin Zone Council. When initially created, the Council consisted of approximately 18 members. Seven members were elected by the industry and the rest were appointed by the Maine DMR. Industry members included three draggers, three divers, one buyer, and one processor from each zone. In addition, two independent (nongovernment) scientists were appointed to the Council. In the same year, open and closed seasons were established (150 days open in Zone 1, and 170 days in Zone 2). Since that time, the fishery has been managed, based on advice from the Council, primarily through input controls, such as reductions in allowable fishing days, seasons, and minimum and maximum size limits. In addition, there are data-reporting requirements and fees to support research and management. Based on the advice and preferences of the Council, the fishery has not been managed with total or individual catch limits, which, as we point out below, would most likely have been very ineffective. Specific regulations vary by zone due to geographic differences in abundance and timing of reproduction. Regulations tend to be limited to measures that are enforceable given the limited financial resources of the agency. These management rules have not been conducive to sustainable use, and informants uniformly note the absence of informal, selfgovernance. When co-management started in 1996, statewide landings were $11,702,880 \mathrm{~kg}$; during the first decade of the this century, landings declined from an average of about $3,719,520 \mathrm{~kg}$ worth about US\$11 million to less than 657,720 $\mathrm{kg}$ worth US $\$ 1.8$ million. Most landings are now taken from Zone 2 because urchins are economically extinct in western Maine (Fig. 1).

\section{Basic sea urchin biology and life history}

The depths at which sea urchins live ranges from tide pools in the low intertidal zone to $300 \mathrm{~m}$, although they are most common in the shallow subtidal zone to $50 \mathrm{~m}$. Urchins are patchily distributed; they are found most often in rocky bottom areas (referred to here as ledges), but also on gravel bottoms in deep water and occasionally on sand (Scheibling and Hatcher 2007). Scientists and divers also report finding them on mud where they appear to feed on patchy growths of diatoms. Densities decline below depths of 20 to $30 \mathrm{~m}$, which is often the lower limit of the rocky subtidal zone. Their upper limit varies seasonally with wave action and ice scouring (Scheibling and Hatcher 2007).

Urchins are generally omnivores, but they exhibit clear food preferences for large brown algae, which forms their primary diet either as attached fronds or drift kelp (Larson et al. 1980, Vadas et al. 2000). Urchins can detect food from a distance of several meters and aggregate around it in response (Vadas and Beal 1999). Their ability to feed on drift kelp allows them to survive where their preferred food does not grow (e.g., in places below the photic zone where drift kelp might collect). In the absence of macroalgae, they can survive by feeding on other items, but with reduced growth and reproduction (Larson et al. 1980).

Well-fed urchins in kelp-grazing aggregations have high somatic growth rates and gonad indices (Scheibling and Hatcher 2007). Urchin roe swells in fall and early winter, while spawning occurs in the spring (Vadas and Beal 1999). The roe is most valuable in the late fall and winter when it is the color, texture, and taste favored by the Japanese market. Urchins usually spawn in their third year, when their diameter is 2.5 to $3.8 \mathrm{~cm}$. A female urchin can produce up to 10 million eggs, i.e., by an $8.0-\mathrm{cm}$ urchin. Urchin roe color, texture, size, and taste vary with what urchins eat, their sex, time of year, and habitat conditions. The Japanese market prefers large, firm, light yellow roe.

The strong interaction between urchins and kelp communities is well documented (McNaught 1999; Harris and Tyrrell 2001; Steneck et al. 2002, Steneck et al. 2004). Meidel and Scheibling (2001) describe shifts in the community state due to changes in urchin abundance and feeding behavior. When urchins are in low abundance, kelp beds thrive. As urchins feed on the kelp (as drift algae or understory plants), they grow and reproduce. As their density increases, large urchins aggregate into "grazing fronts". As they feed extensively on the kelp at this time, along the feedline, their growth and reproduction remains high. Eventually, with a reduction in feed and an increase in the local population, the nutritional state of urchins declines leading to reductions in growth and reproduction. These urchin barrens persist until wave action, ice scouring, or harvesting remove the urchins. Once urchins are eliminated, diatoms and then macroalgae grow rapidly; 
Table 1. Ledge states and relevant characteristics: summary.

\begin{tabular}{|c|c|c|c|c|}
\hline Ledge state & Urchin abundance & $\begin{array}{l}\text { Quality and } \\
\text { price }\end{array}$ & Dominant harvesting strategies & $\begin{array}{c}\text { Nature and value of } \\
\text { fishermen's knowledge about } \\
\text { state. }\end{array}$ \\
\hline a. Barrens & $\begin{array}{l}\text { High. } \\
\text { Initial absence of harvesting. }\end{array}$ & Low. & Unselective. & $\begin{array}{c}\text { Broad-scale, long-term, widely } \\
\text { known, but of little competitive } \\
\text { value. }\end{array}$ \\
\hline \multicolumn{5}{|c|}{$\begin{array}{l}\text { Harvesting causes a transition to conveyor belt state } \\
\text { starts to grow back, urchin roe content increases, few predators } \\
\downarrow\end{array}$} \\
\hline b. Conveyor belt & $\begin{array}{l}\text { Medium. } \\
\text { Sufficient numbers of urchins } \\
\text { left to balance kelp growth. }\end{array}$ & High. & $\begin{array}{c}\text { Moderately selective } \\
\text { (harvesting from feedline). }\end{array}$ & $\begin{array}{c}\text { Ledge specific, short-term, } \\
\text { tightly guarded, competitively } \\
\text { valuable. }\end{array}$ \\
\hline \multicolumn{5}{|c|}{$\begin{array}{l}\text { Heavy, continuous harvesting creates transition to kelp-dominated state } \\
\text { Predators abundant, little or no urchin survival post-settlement }\end{array}$} \\
\hline$\downarrow$ & $\downarrow$ & $\downarrow$ & $\downarrow$ & $\downarrow$ \\
\hline c. Kelp-dominated & Absent or very low. & No fishing. & No fishing. & $\begin{array}{c}\text { Broad-scale, long-term, widely } \\
\text { known, but of little competitive } \\
\text { value. }\end{array}$ \\
\hline
\end{tabular}

kelp beds can become re-established within 2 to 3 years if urchins do not repopulate the ledge. The relevant spatial scale of these processes is on the order of 10 to $200 \mathrm{~m}^{2}$. In an unharvested system, the state of nearby ledges can differ substantially due to the differing effects of water motion, storms, and ice. Recolonization of the kelp beds by urchins occurs through larval settlement and, if they are present, migration of nearby sea urchins from deeper waters.

At a broader scale, Miller and Nolan (2008) describe a migration of urchins on the eastern shore of Nova Scotia. This occurs after widespread, recurrent mortality events caused by a paramoeba that can eliminate urchins to depths of $25 \mathrm{~m}$. Urchins form "a slow-moving belt from deep water to the edge of macrophyte beds [in shallower waters] where harvesting takes place" (Miller and Nolan 2008; also see Scheibling et al. 1999). Disease appears less prevalent in Maine than Nova Scotia due to the shallow waters being much colder; nevertheless, a similar pattern of movement, not accompanied by disease and apparently occurring over much shorter distances, was seen in extremely cold waters in eastern Maine in the 1970s (B. Vadas, personal observation) and is commonly reported by divers. The common element in both migrations is the removal of urchins from shallow water.

There does not appear to be any shortage of larval production in Maine, even in areas where shallow water urchins are near economic extinction (McNaught 1999). Repopulation of ledges, however, can be limited due to crab predation on new recruits (Scheibling 1996, Steneck et al. 2002). Steneck et al. (2002) describe such a local system flip in Maine that occurs as a result of urchin removal via intensive harvesting.
Extirpation of urchins allows for increased growth of kelp forests that provide favorable habitat for large crabs, which in turn prevents urchin recruitment. This kelp-dominated state appears to be relatively long-lived and stable; interviewed participants could not recall any instances of a ledge returning to a state in which urchins were present.

\section{METHODS AND APPROACH}

In this study, we adopted an ethnographic approach, relying on semistructured interviews, as well as on our collective, long-term experience and observation of fishermen and the fishery in this region. The immediate purpose of the interviews was to understand the biophysical and social processes of the fishery so that they could be incorporated in a computational model of adaptive behavior (Holland 1986, Wilson et al. 2007). The description that follows does not describe the modeling approach; rather it emphasizes the multidisciplinary work necessary to reach a qualitative understanding of the multiscale dynamics of the fishery. That understanding is being used to design the computational model.

We conducted eleven semistructured interviews (Bernard 2006) with key informants in the Maine sea urchin industry. All individuals are considered leaders, with knowledge and experience of the fishery since its inception in the late 1980s. We adopted a snowball sampling approach beginning with recommendations from State of Maine scientists. Individuals interviewed included nine divers, one tender/captain, and one buyer. We focused on divers because until recently about $80 \%$ of landings came from divers. As the fishery has declined and moved eastward the number has fallen to about $60 \%$. All but two industry members interviewed were either past members 
or active participants in the Sea Urchin Zone Council, which is the industry advisory panel at the heart of the comanagement system introduced in 1996. In addition, we interviewed three government scientists and four academic scientists involved in the science and management of the fishery. Two of the academic scientists were past members of the Sea Urchin Zone Council.

Interviews ranged from 1.5 to 3 hours and were guided by general questions about the mechanics of fishing operations and markets and changes in the fishery over time as it shifted from abundance to scarcity. These interviews allowed us to understand fishing strategies and operations at multiple scales, from the diver on the bottom, to the captain on the boat, the buyers at the dock, and ultimately the global market based in Japan. All interviews were recorded and detailed notes taken from these recordings; only parts of interviews were transcribed. In addition, discussions with two other academic fisheries scientists and a number of less extensive informal conversations with other divers and draggers provided additional insight into the dynamics of this fishery.

\section{CONCEPTUAL MODEL OF THE RESOURCE}

Based on our analysis of interviews, we describe a conceptual model of the resource that many fishermen and scientists appear to share. The principal dynamic process in the model concerns the different rates of kelp growth, grazing of kelp by urchins, and urchin removal. Typically, when both kelp and urchins are present, urchins tend to aggregate in fronts along the edge of kelp growth. Fishermen call this the feedline and the movement of urchins from deeper water and barren areas to kelp growth as "the conveyor belt". The conveyor belt is often described as a vertical movement of urchins from deep water, but it is fairly clear that horizontal movement also occurs depending on currents and the location of kelp and hungry urchins. The scientific literature describes urchin movement as almost random except when urchins can sense either kelp or possibly urchin feces (B. Vadas, personal communication). In addition, we have developed a simple cellular automata (Netlogo type) model which indicates that the scientists' and fishermen's observations are entirely consistent. Random movements with the ability to sense food from a relatively short distance $(\sim 10 \mathrm{~m})$ generates the movement and the feedlines observed by fishermen.

Below we briefly detail three key states that are critical to this conceptual model (Table 1). We then describe the resulting harvesting strategies and behavior that influences incentives for cooperation or collective action in this fishery. Both descriptions are a synthesis of the information obtained from both fishermen and scientists.

\section{Barrens state}

At the beginning of the fishery in 1986 the ocean bottom was characterized as an urchin barrens with a large population of nearly starving urchins with very low-quality roe (Table 1a). One buyer explained that this barrens state was why fishermen received such low prices at that time. One fisherman explained, "If you get too many [urchins] on the bottom, you're just going to have a lot of junk. You'll bring in a lot ... but you're not going to get paid much.” Under these conditions, fishermen harvested just about everything they could find. Unfortunately, this led to a considerable waste of urchins.

\section{Conveyor belt state}

As the fishery reduced the size of the urchin population, usually at the "top of the ledge", kelp growth occurred and the quality of the remaining urchins improved due to less competition for food. As one fisherman explained, "[O]ver time we would nip at places where there were too many urchins and ... the quality in these places became higher and higher . . . as density decreased. In the first few years, it got a lot better, and the kelp started coming back early."

In this intermediate state (Table 1b), divers describe harvesting urchins preferentially from ledges, particularly at the feedline, where urchins feeding on kelp, or other seaweeds, would yield high quality roe and better prices (Table $1 \mathrm{~b}$ ). One diver explained how the "urchins would come across the barrens ... and they would eat the feed. They would get good [improve their quality]...[we] would always just run the feedline, take all of the urchins along the feed."

They further report that as urchins are removed from the feedline, new urchins from deeper water replenish the area as they move up to feed; this is the "conveyor belt" (Table 1b). As one diver explained, "We would leave the ones down below the feedline. They would move up into feed. Even a couple of months later, they would be harvestable." Another informant explained of divers: "[They would] take the ones feeding from the front of the feeding front, and then leave it alone for a couple of weeks and then go back."

\section{Kelp-dominated state}

Fishermen also describe the kelp-dominated state of the system after extensive harvesting (Table 1c). As one fisherman explained: "You could watch kelp increase year to year . . . [T] he kelp was getting bigger and bigger ... We worked it for quite a few years, but now it's all kelp." Informants describe this state as being dominated by kelp, but also lacking urchins: "Just masses of weed [kelp] and no urchins-more weed because it's not being eaten by urchins. You just see a huge explosion of kelp and periwinkles-just from urchins being cleared out and lots more lobsters."

Fishermen frequently emphasize that these changes were due to what they view as unsustainable harvest practices. In one fisherman's words, "What has really done a lot of damage is that diver who ... keeps pounding them even if they're low quality. They just beat an area to death and the areas flip to the alternate stable state." [The identification of this as an 
"alternate stable state" reflects the above diver's involvement in the co-management system and his interactions with scientists.] While not all divers refer to this in such terms, all divers agree that the system becomes dominated by kelp and the ledge becomes devoid of urchins. Hence, under these conditions, fishermen no longer harvest from these areas.

\section{INDIVIDUAL HARVESTING STRATEGIES}

The conceptual model described above is linked closely with the harvesting strategies that fishermen adopted (Table 1). In the beginning of the fishery, in the barrens state, the most common harvesting strategy was one that emphasized volume with a minimum acceptable level of quality. Determination of urchin quality is problematic. In these circumstances it is common for prices to be based on an average level of acceptable quality (Wilson 1980), but the difficulty of determining quality also encourages game playing. In our interviews, we heard examples of attempts at deception going both ways between urchin buyers and harvesters. One fisherman, for example, explained that they would often "get four or five trays of the not so good stuff [low quality], but then go get the good stuff so it averages out." This was justified because fishermen felt buyers also used a number of deceptive practices, such as inaccurate scales to weigh the urchins, which tended to lower the revenue received by fishermen.

These market conditions were reflected in fishermen's harvesting strategies. In a nondiscriminating market there is little incentive, beyond the low cost of culling, for anyone to leave any urchins behind. Additionally, the essentially open access nature of the resource means that urchins left behind, regardless of quality, are likely to be taken by others, also creating little incentive to leave any. Not surprisingly, there was a perception among fishermen that other fishermen did not care about the future of the resource and, therefore, other fishermen could not be trusted to not take small or low-quality urchins. One fisherman explained: "I know there would be people who would say, 'I'm going to take every last one and then I'm going to do something else.' . . . People would say, 'Why prolong this? Let's just clean it up and move on.' And they did."

One diver spoke about urchin fishermen having a reputation for caring only about money and not the resource. He describes a disincentive to be selective, but still suggests he is one of the exceptions: "It was true to a great extent. I went through spells like that where I thought, 'No one else is taking care of this, why should I? No one else is worried about the smalls.' But I couldn't do that. I wanted to make money the following year. I don't disturb the smalls because I hope they'll be there next year." According to another diver, "[t]he better divers would pick one at a time and leave the bigger ones and the little ones alone," but not all fishermen were selective. Many would "rake everything up into a bag and send them up and then cull on the boat; a lot of those little ones wouldn't make it."
Some fishermen also argue that an unselective harvesting strategy is an attribute of the boats and the equipment that the fishermen had. The places that small boat fishermen-in 6 to $9 \mathrm{~m}$ vessels, sometimes referred to as "wolf packs" or "the mosquito fleet" - can access are limited due to the size of their boat. They must fish closer to shore compared to larger vessels, and they cannot operate safely in high wind conditions. Because of these limitations, they cannot afford to be selective and are more likely to "straight rake", taking whatever they find and culling on the boat. It is in their best interest to take what they can find, when they can find something; they can always dump the low-quality urchins later if they come across better ones, but at least they are able to bring in something to the market at the end of the day. It is possible that regulations that limit the days divers are able to fish also encourage similar behavior.

As the fishery matured, buyers became more selective, more often using prices to discriminate between urchins of different quality. This change in the market led to greater selectivity in harvesting. As mentioned, fishermen began to work the top of the ledge, leaving urchins located in deeper water or barrens, of which there were fewer and fewer. For several years there was a small market that shipped live urchins to Japan. Buyers in this market paid a substantial premium (about twice the going price) for consistently good quality urchins. Fishermen supplying these buyers appear to have established persistent one-on-one relationships with their buyer. These relationships appear to mitigate the quality determination issue, leading fishermen selling into this market to practice selective harvesting simply because it paid off.

\section{SEARCH AND INFORMATION SHARING}

The knowledge fishermen have of the resource and the methods they use to acquire it are the principal determinants of their competitive and cooperative relationships with other fishermen, which are considered a key element for selfgovernance or community management. When fishermen search for mobile resources, the advantages of sharing can be very beneficial and will be used if fishermen can develop norms for equitable reciprocation (Wilson 1990, Wilson et al. 2007). In the urchin fishery, however, information sharing and even the most rudimentary forms of self-governance appear absent. The reason is that the resource is very sedentary and even though fishermen have a very good sense of likely places to search, that knowledge is rather durable; consequently, it is known by most fishermen and is not the basis for cooperation.

Our interviews indicate that some knowledge that is valuable to an urchin diver is broadly available and relatively long lasting. The location of likely urchin habitat, for example, is readily apparent from any navigation chart. Thus, knowledge about the broad-scale attributes of the resource is of little competitive value. Other knowledge is fine scale, private, of short-term value, and tightly guarded. This knowledge 
concerns the current state of particular ledges. It enhances a diver's competitive position, and thus is of considerable value.

Oversimplifying somewhat, a harvester might encounter one of three very different resource states on a ledge.

\section{An urchin barren in which starving or underfed urchins} are extremely abundant (Table 1a). When the entire fishery is in this state, the value of knowledge about the resource is close to zero because anyone can find urchins.

2. An intermediate, or conveyor belt, state in which a ledge is fished but has not flipped (Table 1b). This is a dynamic state in which the harvestable condition of the resource can change unpredictably in a short period of time in response to harvesting or weather. Any knowledge a fisherman has about the current state of a ledge is valuable because it is the key to when that ledge might be harvested most profitably. This is the knowledge a fisherman needs to make a living.

3. An urchin-extirpated, kelp-dominated ledge in which harvesting has caused a local system flip (Table 1c). This is a long-lived or stable state; the principal value of the fisherman's knowledge about ledges in this state lies in the avoidance of a useless search.

Our interviews indicate that fishermen keep a substantial list of good places to search for urchins-“conveyor belt" ledges -in their head; the duration of knowledge about where to search is rather long but the current state of any conveyor belt ledge can only be confirmed by direct observation. The harvestable state of a ledge depends upon recent harvest activity, the growth of kelp and the movement of urchins to the top of the ledge (Vadas and Beal 1999). The speed of this response varies from ledge to ledge, depending upon the time of year, depth of the disturbance, and the distance urchins must travel to the top. The topography of the ledge also appears important. Urchins can move to the "top" of a steeply sloped ledge rather quickly; a ledge with a long, shallow slope, on the other hand, might be prone to the removal of urchins over a large area, making it hard for urchins "moving up from the bottom" to graze down kelp growth; this allows the growth of predators and increases the likelihood that the ledge will transition to a flipped state.

If it were not for the harvesting activities of other fishermen, divers might be able to predict the state of individual ledges rather well. But, fishermen have a hard time keeping track of the activities of other harvesters; consequently, their decision about where to fish on any particular day depends on their knowledge of their own recent activities and costly, quick searches of "promising" ledges they have not been worked recently but that might have been worked by other fishermen. Searching is particularly costly in the current fishery because harvesting is permitted only for a limited number of days: 10 in the west (Zone 1) and 45 in the east (Zone 2). Consequently, effort spent searching reduces valuable harvesting time. Fishermen adapt to these circumstances by searching on days when the fishery is closed and, especially, by developing exploratory techniques that allow them to quickly assess a ledge, for example, by motoring over it at low tide, using glass bottom buckets and, when necessary, popping in and out of the water for short dives. All our informants report that when urchins are found this way, searching stops and harvesting begins. This very close connection between discovery and harvesting leaves little room for reciprocal information sharing. Even when a productive ledge has to be abandoned with the onset of darkness, sharing knowledge of the location simply means unwanted competition in the morning. As one of our informants put it, it would be like "handing the guy my wallet."

In short, the following all combine to virtually eliminate any benefits from information sharing: the particular scale of postsettlement urchin life history, the dynamics of urchin and kelp interaction, the biological thresholds that determine urchin barrens and kelp domination, the influence of the market on harvesting practices, and the problems of prediction and search faced by divers. As a result there are no long-term or even short-term cooperative relationships or even informal rules that might contribute to efficient harvesting or act as a foundation for successful collective action. From this finescale perspective, the broad-scale rules currently used to manage the fishery, including the co-management system, appear to be nearly irrelevant to the sustainability of the resource. They do not address the biological dynamics that determine the sustainability of each ledge and they do little to restrain open access incentives. This perspective suggests finer scale management and exclusive rights schemes might restrain open access incentives; however, as we discuss below policies designed along these lines and applied in the Atlantic provinces of Canada do not seem to have produced the expected results.

\section{DISCUSSION AND CONCLUSION}

Scale mismatches in the ocean results in management institutions that are not able to obtain appropriate feedback about the effect of human activity; this impairs the ability to learn and adapt and is a common cause of resource depletion (Berkes and Folke 1998, Young 2002, Berkes et al. 2006, Crowder et al. 2006, Wilson 2006, Folke et al. 2007). Management in the Maine sea urchin fishery included limits on access and a co-management structure, both of which are viewed as necessary in order to avoid the tragedy of the commons (Feeny et al. 1990, Wilson et al. 2003). Yet the resource continued to decline and remains in a depleted condition. Our analysis suggests the most fundamental cause of the decline in the Maine sea urchin fishery was a scale 
mismatch; co-management was applied at a scale that was not congruent with the biological scale appropriate for sustainability.

If there is any biophysical basis for sustainability in the Maine sea urchin fishery it would appear to be in the management of the conveyor belt on each ledge, where the system has not yet flipped to the kelp-dominated state. However, the scale of the conveyor belt is far smaller than the relevant scale of an individual harvesting operation (which might be in the order of 10 to 15 ledges) and is certainly much smaller than the 160 $\mathrm{km}$ or more extent of each of the sea urchin co-management zones. The incentives that emerge from the social and ecological dynamics of the resource make it nearly impossible for individual fishermen to conserve the resource because they cannot be assured that others will do so also. Thus, for all practical purposes, the scale of management institutions maintains an open access system at the scale most relevant to fishermen's behavior and the ecology of the sea urchin, resulting in a tragedy of the commons situation. Consequently, just as government control and privatization do not always work to circumvent the tragedy of the commons (Feeny et al. 1990), co-management, too, sometimes is insufficient for sustainability. This case underscores the importance of paying attention to the fine-scale dynamics of coupled human and natural systems, and the need to tailor management rules to local conditions.

In the Maine sea urchin fishery, the particular social and ecological conditions suggest the appropriate management system would be one where a fisherman or a small group of fishermen had exclusive harvesting rights to a ledge or a group of ledges in a bay, for example. In theory, such a system would be more likely to create incentives for fishermen to practice sustainable harvesting techniques because they would be assured the benefit of their conservation. However, such exclusive harvesting rights systems have been tried elsewhere, for example in Canada and Chile, with mixed success.

An individual leasehold approach was tried on the eastern shore of Nova Scotia, Canada (Miller and Nolan 2008). Leaseholders were given exclusive access to an area of the ocean and the responsibility for managing the stock in their zone (Miller 2008). They were required to participate in monitoring and enhancement, but were not subjected to seasons or catch limits. Enhancement included moving kelp to locations where urchins were overcrowded or starving, and adjusting harvesting intensity as necessary to maintain the feedline (or grazing front) at an acceptable depth. The system allowed fishermen more flexibility to target high prices because they could leave urchins behind "without fear of losing their stock to another fishery," and indeed at times refused to sell because of low prices. Leaseholders fished selectively, but engaged in minimum stock enhancement (Miller 2008). Canadian officials report the leasehold approach was unsuccessful partly because the scale of the leaseholds was often too large for an individual holder to manage (Miller and Nolan 2008). Furthermore, it is possible that the fear of disease was enough to create disincentives for fishermen to invest in the future of the fishery. Fishermen focused their harvesting efforts on a few productive places within their exclusive area, what Miller (2008) calls areal high grading. At the end of the 4-year trial period, only 1 of 14 leasehold zones had met criteria for being well managed (i.e., less than $1000 \mathrm{~m}$ of feeding line front at $<6 \mathrm{~m}$ depth). It is also not clear from the Canadian scientific literature or from our brief discussions with scientists and one fisherman whether other aspects of the fishery, outside the control of leaseholders, led to the apparent reluctance to invest in the resource. Maine's sea urchin fishery, at least so far, has been relatively immune to the disease that affected the Nova Scotian fishery, although there was a small outbreak in 1999. More data are needed to assess if key differences in biophysical circumstances (mainly temperature and oceanographic conditions) in Nova Scotia imply different outcomes from such a leasehold system in Maine.

On the other hand, an area-based management system for benthic species, including sea urchins, seemed to work well in Chile (Moreno et al. 2007). Following economic liberalization in the 1980s, Chile enacted legislation designating exclusive fishing zones for small-scale fishermen and introduced the concept of management areas (Cancino et al. 2007). Within this rights-based management system, known as TURFs (Territorial User Rights in Fisheries), fishermen's associations are allocated exclusive fishing rights to areas. In the case of sea urchin management within the TURF system, fishermen evaluate the abundance of the resource within their area and determine the stock status with the help of a consultant (Moreno et al. 2007). This system has been "successful in the conservation and management of artisanal fisheries for valuable benthic species, including sea urchins" (Moreno et al. 2007:46).

However, even where TURFs were not established in Chile in regions $\mathrm{X}-\mathrm{XI}$ in the south, landings have been stable for two decades (Moreno et al. 2007). In this region, the fishery is highly mobile and expands and contracts over an area covering four latitudinal degrees (Moreno et al. 2007). Rather than long term serial depletion as occurred in Maine, Moreno et al. (2007) describe the dynamics in the sea urchin fishery in this area as one of "depletion and recovery" over a period of two decades. Similar to what we have seen in Maine, they report that short-term recovery may be the result of urchins moving from refuge areas into depleted areas, with fishermen reporting refuges in depths beyond which divers can reach. They also report the common practice of fishermen to "deplete a good procedencia [fishing area] at the beginning of the season, abandon it temporarily, and then return towards the end of the season." A study to explore spatially-explicit management 
strategies found "spontaneous rotation of fishing areas at different scales" and "large areas that are not harvested" (Moreno et al. 2007:56). Despite a management system similar to that seen in Maine, i.e., limited access without exclusive harvesting rights, the fishery in Chile appears to have avoided the kind of local level serial depletion seen in Maine's fishery.

In Maine the long-term, almost permanent consequences of overfishing is attributable to local system flips. If this kind of threshold had not existed in Maine, the history of the fishery might have been very different. In Chile these threshold effects do not appear to be a problem although there is uncertainty regarding recruitment and post-settlement processes (Moreno et al. 2007). Future research should aim to better understand the ecological circumstances driving the fishery in Chile in order to better assess the feasibility of an area-based management system in Maine.

An in-depth analysis of these and other cases are outside the scope of this paper. However, clearly these case studies remind us that sustainable resource use requires mechanisms that adapt rules to the particular local circumstances. What works, or does not work, in Chile or Canada may not have the same outcome in Maine because the particular social and biophysical conditions that matter most for sustainability differ. Institutional design must consider how to restrain fishermen's behavior in ways that are aligned with the particular fine-scale social and ecological dynamics of a given resource. Following Ostrom (2007), we reiterate that there are no panaceas. From our perspective, knowledge of the coupled natural and human system at the fine scale is necessary if we are to assess the feasibility of particular management institutions.

Finally, our interviews and the accompanying scientific literature make it clear that the factors affecting sustainability in this fishery have to be modeled at a relatively fine scale. The mechanisms that eventually emerge as widespread depletion occur at the scale of the individual ledge (Fig. 2). When viewed from this perspective, the usual broad-scale perspective of the overfishing problem (seen in Fig. 1) is not meaningful except as a broad statistical description that is unconnected to the actual mechanisms of depletion. In a patchy complex environment, overfishing is a relatively fine-scale process that removes, piece-by-piece, discrete, local aggregations. Consequently, modeling the fishery at broader scales is not a way to capture the dynamics affecting sustainability and, as the history of the fishery has shown, is clearly not the scale at which modeling might provide insights for practical management.

Responses to this article can be read online at: http://www.ecologyandsociety.org/vol17/iss2/art15/ responses/

\section{Acknowledgments:}

This material is based on work supported by the Dynamics of Coupled Natural and Human Systems Program of the National Science Foundation under Grant No. 0909449, "Fine-Scale Dynamics of Human Adaptation in Coupled Natural and Social Systems: An Integrated Computational Approach Applied to Three Fisheries" (P.I.: James Wilson). Any opinions, findings, and conclusions or recommendations expressed in this material are those of the authors and do not necessarily reflect the views of the National Science Foundation. We also thank Maggie Hunter and Robert Russell from the Maine Department of Marine Resources for providing data on the fishery and, of course, we also thank our key informants from the Maine sea urchin industry for their time and willingness to participate in our study.

\section{LITERATURE CITED}

Acheson, J. M. 2003. Capturing the commons: devising institutions to manage the Maine lobster industry. University Press of New England, Lebanon, New Hampshire, USA.

Agrawal, A. 2003. Sustainable governance of common-pool resources: context, methods, and politics. Annual Review in Anthropology 32:243-262. http://dx.doi.org/10.1146/annurev. anthro.32.061002.093112

Andrew, N. L., Y. Agatsuma, E. Ballesteros, A. G. Bazhin, E. P. Creaser, D. K. A. Barnes, L. W. Botsford, et al. 2002. Status and management of world sea urchin fisheries. Oceanography and Marine Biology Annual Review 40:343-425.

Basurto, X. 2005. How locally designed access and use controls can prevent the tragedy of the commons in a Mexican small-scale fishing community. Society and Natural Resources 18(7):643-659. http://dx.doi.org/10.1080/0894192 $\underline{0590959631}$

Basurto, X. 2008. Biological and ecological mechanisms supporting marine self-governance: the Seri callo de hacha fishery in Mexico. Ecology and Society 13(2):20. [online] URL: www.ecologyandsociety.org/vol13/iss2/art20/.

Berkes, F., and C. Folke. 1998. Linking social and ecological systems for resilience and sustainability. Pages 1-25 in F. Berkes and C. Folke, editors. Linking social and ecological systems: management practices and social mechanisms for building resilience. Cambridge University Press, New York, New York, USA.

Berkes, F., T. P. Hughes, R. S. Steneck, J. A. Wilson, D. R. Bellwood, B. Crona, C. Folke, et al. 2006. Globalization, roving bandits, and marine resources. Science 311 (5767):1557-1558. http://dx.doi.org/10.1126/science.1122804 
Bernard, H. R. 2006. Research methods in anthropology: qualitative and quantitative approaches. Fourth edition. Altamira Press, Walnut Creek, California, USA.

Borgström, S. T., T. Elmqvist, P. Angelstam, and C. AlfsenNorodom. 2006. Scale mismatches in management of urban landscapes. Ecology and Society 11(2):16. [online] URL: w ww.ecologyandsociety.org/vol11/iss2/art16/.

Botsford, L. W., A. Campbell, and R. Miller. 2004. Biological reference points in the management of North American sea urchin fisheries. Canadian Journal of Fisheries and Aquatic Sciences 61:1325-1337. http://dx.doi.org/10.1139/f04-131

Cancino, J. P., H. Uchida, and J. E. Wilen. 2007. TURFs and ITQs: collective vs. individual decision making. Marine Resource Economics 22:391-406.

Cash, D. W., W. Adger, F. Berkes, P. Garden, L. Lebel, P. Olsson, L. Pritchard, and O. Young. 2006. Scale and crossscale dynamics: governance and information in a multilevel world. Ecology and Society 11(2):8. [online] URL: www. ecologyandsociety.org/vol11/iss2/art8

Chen, Y., and M. Hunter. 2003. Assessing the green sea urchin (Strongylocentrotus drobachiensis) stock in Maine, USA. Fisheries Research 60(2-3):527-537. http://dx.doi.org/10.1016/ S0165-7836(02)00082-6

Crowder, L. B., G. Osherenko, O. R. Young, S. Airame, E. A. Norse, N. Baron, J. C. Day, F. Douvere, C. N. Ehler, B. S. Halpern, S. J. Langdon, K. L. McLeod, J. C. Ogden, R. E. Peach, A. A. Rosenberg, and J. A. Wilson. 2006. Resolving mismatches in U.S. ocean governance. Science 313 (5787):617-618. http://dx.doi.org/10.1126/science.1129706

Cumming, G. S., D. H. M. Cumming, and C. L. Redman. 2006. Scale mismatches in social-ecological systems: causes, consequences, and solutions. Ecology and Society 11(1):14. [online] URL: http://www.ecologyandsociety.org/vol11/iss1/ art14/.

Dyer, C., and J. R. McGoodwin. 1994. Folk management in the world's fisheries: lessons for modern fisheries management. University Press of Colorado, Niwot, Colorado, USA.

Feeny, D., F. Berkes, B. J. McCay, and J. M. Acheson. 1990. The tragedy of the commons: twenty-two years later. Human Ecology 18(1):1-19. http://dx.doi.org/10.1007/BF00889070

Folke, C., L. Pritchard, F. Berkes, J. Colding, and U. Svedin. 2007. The problem of fit between ecosystems and institutions: ten years later. Ecology and Society 12(1):30. [online] URL: http://www.ecologyandsociety.org/vol12/iss1/art30/.

Harris, L. G., and M. C. Tyrrell. 2001. Changing community states in the Gulf of Maine: synergism between invaders, overfishing and climate change. Biological Invasions 3:9-21. http://dx.doi.org/10.1023/A:1011487219735

Hilborn, R. 2007. Defining success in fisheries and conflicts in objectives. Marine Policy 31(2):153-158. http://dx.doi.org /10.1016/j.marpol.2006.05.014

Holland, J. H. 1986. Escaping brittleness: the possibilities of general-purpose learning algorithms applied to parallel rulebased systems. Pages 593-624 in R. S. Michalski, J. G. Carbonell, and T.M. Mitchell, editors. Machine learning, an artificial intelligence approach. Morgan Kaufmann, San Francisco, California, USA.

Hutchings, J. A., and J. D. Reynolds. 2004. Marine fish population collapses: consequences for recovery and extinction risk. BioScience 54(4):297-305. http://dx.doi.org/1 0.1641/0006-3568(2004)054[0297:MFPCCF]2.0.CO;2

Larson, B. R., R. L. Vadas, and M. Keser. 1980. Feeding and nutritional ecology of the sea urchin Strongylocentrotus drobachiensis in Maine, USA. Marine Biology 59:49-62. htt p://dx.doi.org/10.1007/BF00396982

Laur, S. R. 2001. Flexible production on the working waterfront: the social origins of the northwest Atlantic sea urchin industry. Rural Sociology 66:532-556. http://dx.doi.or g/10.1111/j.1549-0831.2001.tb00083.x

Laur, S. R. 2005. Entrepreneurial processes in an emergent resource industry: community embeddedness in Maine's sea urchin industry. Rural Sociology 70:145-166. http://dx.doi.or g/10.1526/0036011054776406

Liu, J., T. Dietz, S. R. Carpenter, M. Alberti, C. Folke, E. Moran, A. N. Pell, et al. 2007. Complexity of coupled human and natural systems. Science 317(5844):1513-1516. http://dx. doi.org/10.1126/science.1144004

McCay, B. J., and J. M. Acheson. 1987. The question of the commons: the culture and ecology of communal resources. University of Arizona Press, Tucson. Arizona, USA.

McNaught, D. 1999. The indirect effects of macro algae and miropredation on the post-settlement success of the green sea urchin in Maine. Unpublished doctoral thesis. University of Maine, Orono, Maine, USA.

Meidel, S. K., and R. E. Scheibling. 2001. Variation in egg spawning among subpopulations of sea urchins Strongylocentrotus droebachiensis: a theoretical approach. Marine Ecology Progress Series 213:97-110). http://dx.doi.org/10.3354/meps $\underline{213097}$

Miller R. J. 2008. A sea urchin diver fishery managed by exclusive fishing areas. Pages 7787 in R. Townsend, R. Shotton, and H. Uchida, editors. Case studies in fisheries selfgovernance. FAO Technical Report 204. Food and Agriculture Organisation, Rome, Italy. 
Miller, R. J., and S. C. Nolan. 2008. Management methods for a sea urchin dive fishery with individual fishing zones. Journal of Shellfish Research 27(4):929-938. http://dx.doi.org/10.298 3/0730-8000(2008)27[929:MMFASU]2.0.CO;2

Moreno, C. A., N. Barahoma, C. Molinet, J. M. Orensanz, A. M. Parma, and A. Zuleta. 2007. From crisis to institutional sustainability in the Chilean sea urchin fishery. Pages 593-624 in T. McClanahan and J.C. Castilla, editors. Fisheries management: progress toward sustainability. Blackwell Publishing, Ames, Iowa, USA. http://dx.doi.org/10.1002/978 $\underline{0470996072 . c h 3}$

Myers, R. A, and B. Worm. 2003. Rapid worldwide depletion of predatory fish communities. Nature 423:280-283. http://dx. doi.org/10.1038/nature01610

Ostrom, E. 1990. Governing the commons: the evolution of institutions for collective action. Cambridge University Press, Cambridge, England.

Ostrom, E. 2007. A diagnostic approach for going beyond panaceas. Proceedings of the National Academy of Sciences 104(39):15181-15187. http://dx.doi.org/10.1073/pnas.0702288104

Pauly, D., V. Christensen, S. Guénette, T. J. Pitcher, U. Rashid Sumaila, C. J. Walters, R. Watson, and D. Zeller. 2002. Towards sustainability in world fisheries. Nature 418:689-695. http://dx.doi.org/10.1038/nature01017

Scheibling, R. E. 1996. The role of predation in regulating sea urchin populations in eastern Canada. Oceanologica Acta. 19:421-430.

Scheibling, R. E., and B. G. Hatcher. 2007. Chapter 18: ecology of Strongylocentrotus droebachiensis. Developments in Aquaculture and Fisheries Science 37:353-392. http://dx.d oi.org/10.1097/00002826-197900040-00006

Scheibling, R. E., A. W. Hennigar, and T. Balch. 1999. Destructive grazing, epiphytism, and disease: the dynamics of sea urchin-kelp interactions in Nova Scotia. Canadian Journal of Fisheries and Aquatic Sciences 56(12):2300-2313. http://d x.doi.org/10.1139/cjfas-56-12-2300

Seward, L. C. N. 2002. The relationship between spring phytoplankton blooms, sea urchin spawning, and the winterspring hydrography of selected sites in Maine. Masters thesis. University of Maine, Orono, Maine, USA.

Steneck, R. S., M. H. Graham, B. J. Bourque, D. Corbett, J. M. Erlandson, J. A. Estes, and M. J. Tegner. 2002. Kelp forest ecosystems: biodiversity, stability, resilience and future. Environmental Conservation 29(04):436-459. http://dx.doi.or $\mathrm{g} / 10.1017 / \mathrm{S} 0376892902000322$

Steneck, R. S., J. Vavrinec, and A. V. Leland. 2004. Accelerating trophic-level dysfunction in kelp forest ecosystems of the western North Atlantic. Ecosystems 7 (4):323-332. http://dx.doi.org/10.1007/s10021-004-0240-6

Vadas, R. L., and B. F. Beal. 1999. Relationships between adult size, maturity and fecundity in green sea urchins: the potential use of a roe-yield standard as a conservation tool. Final Report. Maine Department of Marine Resources, Boothbay Harbor, Maine, USA.

Vadas, R. L., B. Beal, T. Dowling, and J. C. Fegley. 2000. Experimental field tests of natural algal diets in the green sea urchin, Strongylocentrotus droebachiensis: a case for rapid summer production in post-spawned animals. Aquaculture 182:115-135. http://dx.doi.org/10.1016/S0044-8486(99)00254-9

Wilson, D. C., J. Raakjr Nielsen, and P. Degnbol. 2003. The fisheries co-management experience: accomplishments, challenges, and prospects. Vol. 26, Fish and Fisheries Series. Kluwer Academic Publishers, Boston, Massachusetts, USA.

Wilson, J. 1990. Fishing for knowledge. Land Economics 66 (1):12-29. http://dx.doi.org/10.2307/3146679

Wilson, J., L. Yan, and C. Wilson. 2007. The precursors of governance in the Maine lobster fishery. Proceedings of the National Academy of Sciences 104(39):15212-15217. http://d x.doi.org/10.1073/pnas.0702241104

Wilson, J. A. 1980. Adaptation to uncertainty and small numbers exchange: the New England fresh fish market. Bell Journal of Economics 11(2):491-504. http://dx.doi.org/10.23 $\underline{07 / 3003375}$

Wilson, J. A. 2006. Matching social and ecological systems in complex ocean fisheries. Ecology and Society 11(1):9. [online] URL: www.ecologyandsociety.org/vol11/iss1/art9/

Worm, B., E. B. Barbier, N. Beaumont, J. E. Duffy, C, Folke, B. S. Halpern, J. B. C. Jackson, et al. 2006. Impacts of biodiversity loss on ocean ecosystem services. Science 314 (5800):787-790. http://dx.doi.org/10.1126/science.1132294

Young, O. R. 2002. The institutional dimensions of environmental change: fit, interplay, and scale. MIT Press, Cambridge, Massachusetts, USA. 